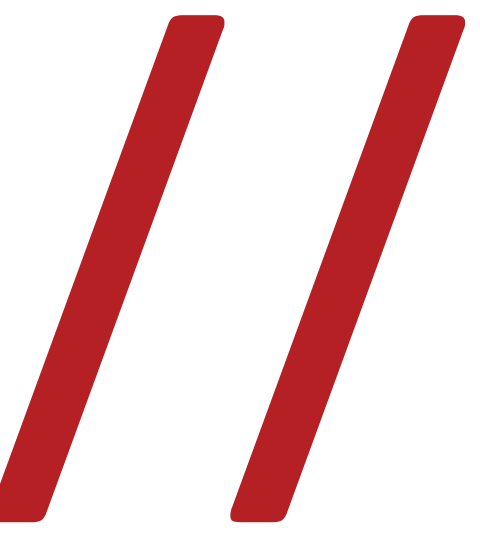

\title{
0 fundo do ar é vermelho: a subterrânea matéria sensivel da história
}

\section{A grin without a cat: the subterranean sensitive matter of history}

\section{André Brasil ${ }^{1}$ \\ Julia Fagioli²}

\footnotetext{
${ }^{1}$ Pesquisador do Conselho Nacional de Desenvolvimento Científico e Tecnológico (CNPq) e professor do Departamento de Comunicação da Universidade Federal de Minas Gerais (UFMG), onde integra o corpo docente permanente do Programa de Pós-graduação. Participa do grupo de pesquisa Poéticas da Experiência, junto do qual desenvolve o projeto Formas de vida na imagem: biopolítica, perspectivismo e cinema (Fapemig e CNPq). André Brasil é um dos editores da revista Devires Cinema e Humanidade. E-mail: agbrasil@uol.com.br

${ }^{2}$ Doutora pelo Programa de Pós-Graduação em Comunicação Social da Universidade Federal de Minas Gerais (UFMG). Atuou como professora substituta no curso de Comunicação Social da mesma instituição. Coordenou e organizou o Dossiê: Documentário e Cinema de Arquivos da revista Devires - Cinema e Humanidades. Realizou trabalho de curadoria da Mostra Contemporânea Brasileira do Fórum.doc em 2016. E-mail: julia.fagioli@gmail.com
} 
Resumo: muito se pode dizer sobre O fundo do ar é vermelho, de Chris Marker, filme inesgotável, que se dedica a um impressionante acervo de imagens de nossa história recente. Acervo que somente em parte (sua ponta visível) veio à tona e cuja outra parte, submersa, interessa a Marker retomar. Em nossa hipótese, trata-se, por um lado, de prosseguir com a tradição dialética que produz choques, contradições entre imagens e testemunhos, levando-os sempre em direção a uma polifonia. Por outro lado, a montagem atravessa a dialética pela série paratática - inventário de rostos, gestos e "motivos" - que, em sua dimensão marcadamente patética, modula o filme por meio dos afetos da luta e do luto.

Palavras-chave: Chris Marker; O fundo do ar é vermelho; revolução; dialética; série.

Abstract: much can be said about A grin without a cat by Chris Marker, a limitless film that devotes itself to a striking collection of images from our recent history. Only a small part of this collection (its visible tip) has emerged, the submerged part is what Marker was interested on surfacing. Our hypothesis is that, on one hand, the film is about pursuing the dialectical tradition that produces clashes and contradictions between images and testimonies, leading them towards a polyphony. On the other hand, the montage crosses the dialectics through the paratactic series - an inventory of faces, gestures and "motives" that modulate the film through affections of struggle and mourning.

Keywords: Chris Marker; A grin without a cat; revolution; dialectics; series. 


\section{Carta de intenções}

Em uma carta de intenções (apud GIRAUD, 2013) escrita logo após o golpe de Estado no Chile, Chris Marker manifesta seu desejo de retornar às imagens de 1967 a 1973 (período que acabou se prolongando até 1977). Um filme, nos diz, possui dois pontos em comum com um iceberg: com o tempo, dele restará cada vez menos e sua parte invisível (submersa) será sempre maior que sua parte visível. Qual cineasta, nos pergunta Marker, não desejou reunir suas sobras, reconsiderá-las? Se os filmes feitos, no geral, descrevem o tempo dos acontecimentos e das ações, as sobras - as cascas - descrevem o tempo da reflexão.

O diretor encerra sua carta dizendo que, ao retomar imagens desse período em específico, é possível perceber as modulações e metamorfoses do tema da revolução naquele momento, a partir de um inventário que ele trata de esboçar: as greves do início de 1967; uma viagem do próprio Marker à Bolívia cujos registros jamais foram utilizados; numerosos registros de Maio de 1968, entre eles, uma filmagem, em cores, das barricadas; o Maio de 1968 visto por seus opositores; os Jogos Olímpicos no México e o massacre de Tlatelolco; documentos sobre o Chile da Unidade Popular; o Uruguai dos Tupamaros; a repressão no Brasil; uma antologia das inscrições nos muros de Paris; registros de diferentes momentos no Vietnã; a Festa dos Gatos em Ypres. E, finalmente, cartas em cassete, enviadas clandestinamente de vários países.

Muito se pode dizer (e se disse) $)^{3}$ sobre esse filme enorme, inesgotável, que se dedica a um impressionante acervo de imagens de nossa história recente. Acervo que somente em parte (sua ponta visível) veio à tona e cuja outra parte, submersa, interessa a Marker retomar. Como essa memória invisível - esquecimentos da montagem de filmes anteriores - retorna em O fundo do ar é vermelho? Em nossa hipótese, trata-se, por um lado, de prosseguir - não sem transformá-la - com a tradição dialética que, no filme, produz choques, contradições entre imagens e testemunhos, levando-os sempre em direção a uma polifonia, que adia a síntese para complexificá-la. Por outro lado, a montagem atravessa a dialética pela série paratática - inventário de rostos, gestos e "motivos" - que, em sua dimensão marcadamente patética, modula o filme por meio dos afetos da luta e do luto. De um lado, portanto, a natureza sempre contraditória

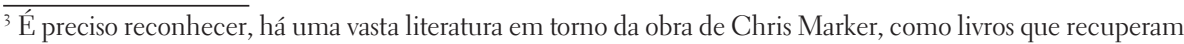
a trajetória do diretor, do início da carreira até os últimos filmes, tais como Alter (2006) e Lupton (2005). Há, ainda, artigos dedicados especificamente ao filme, como Baecque (2008), Casanova (2013), Fairfaix (2012) e Giraud (2013). No Brasil, destacam-se as pesquisas recentes de Carolina Aguiar (2013) e Leonel (2010).
} 
e agonística da revolução, que, no contexto de 1968 (e seu entorno), ganha tessitura polifônica. De outro, seu pathos subterrâneo, que nos faz perceber sobrevivências, recorrências e ressonâncias - e ainda transformações - nos rostos e nos gestos que compõem a história das revoluções.

Neste artigo, não nos dedicaremos a um trabalho exaustivo sobre o filme - de fato, já bastante abordado -, senão indicaremos, em uma série de notas, alguns efeitos dessa dimensão patética, que ganha expressividade, na montagem, por meio de, entre outros procedimentos: os comentários em voz over - enunciados por pessoas próximas ao diretor - não verticais, mas laterais em relação às imagens; a trilha sonora sintética e os filtros coloridos, estes, também formas de comentar as imagens.

\section{Crepúsculo e espiral da história}

A bola vermelha em fundo preto diminui, num instante, até se transformar na letra "o" de "rouge". Por meio desse gesto gráfico, ao mesmo tempo conciso e sofisticado, forma-se, em letras vermelhas sobre fundo preto, o título do filme em francês: Le fond de l'air est rouge $e^{4}$ Na esteira de Vincent Casanova (2013), diríamos que o movimento, tão breve, da tipologia reencontra e enfatiza certo tom crepuscular que o título sugere: o crepúsculo que se lança sobre Maio de 1968, fazendo da luta simultaneamente uma experiência de luto (luto que se precisa elaborar para que a luta se renove).

O círculo remete também, como lembra ainda Casanova (2013), à espiral do tempo de Um corpo que cai (Alfred Hitchcock, 1958), temporalidade já acionada, de algum modo, em La Jeteé (1962) e em Sem Sol (1983): o que permanece ao fundo da mudança e o que se altera - se modula e se singulariza - naquilo que permanecera.

\section{Inventário dos corpos em luta}

As primeiras imagens de $O$ fundo do ar é vermelho funcionam, de certa forma, como uma galeria - ou melhor, um inventário - do imaginário da luta política. Nos quatro minutos iniciais do filme, concentra-se grande quantidade de

\footnotetext{
${ }^{4}$ O filme possui, ao todo, quatro versões: a primeira delas, de 1977 , tem quatro horas de duração e foi produzida logo após período de militância mais intensa, em relação ao qual Marker elabora uma espécie de balanço. Em 1988, ele retornou ao filme, reduzindo sua duração para três horas. Em 1993, em uma nova retomada, acrescentou comentários que analisam imagens de maneira ainda mais perspectivada. Em 1998, estabelece uma última versão em razão da retrospectiva Marker mémoire, organizada pela Cinemateca Francesa. Há, nesse caso, pequenos ajustes de legenda. Em nossa análise, nos valemos principalmente da versão de 1998. O movimento das letras do título, vale dizer, não existia na primeira versão do documentário, de 1977, que era introduzida apenas pelas letras vermelhas em fundo preto.
} 
planos curtos, imagens das manifestações, das barricadas e da repressão policial. O contexto das imagens não é sempre o mesmo, o que sugere já a montagem de uma série paratática: em gesto introdutório, Marker retoma passagens d'O encouraçado Potemkin (S. Eisenstein, 1925), que são intercaladas com registros das lutas dos anos 1960 e 1970.

A referência de Marker a Eisenstein, sabemos, está longe de ser fortuita: ela sugere uma herança assumida, reivindicada e, ao mesmo tempo, deslocada, transformada. Algo a que alude, ainda durante a cartela de abertura, a primeira narração, em voz over de Simone Signoret (1921-1985):

Não sou daqueles que viu O encouraçado Potemkin na estreia. Lembro-me do plano da carne cheia de vermes, com certeza, e da pequena tenda na qual puseram o morto e diante da qual para a $l^{a}$ pessoa. $E$ quando os marinheiros apontavam as armas na ponte do encouraçado. E quando o oficial ordenava fogo, um marinheiro de bigodes que gritava uma palavra que aparecia em letras garrafais: Irmãos! $!^{5}$ (O FUNDO DO AR É VERMELHO, 1998)

Aqui, o filme apresenta-se já defasado em relação aos arquivos que ele convoca, especificamente em relação à ficção eisensteiniana. Antes de tudo, a dúvida: quem assume a primeira pessoa do texto, o próprio Marker (que o teria elaborado) ou Signoret (que estaria enunciando ali seu próprio testemunho)? Em seguida, o tom já distanciado da narração que, de um lado, presta homenagem ao cinema de Eisenstein e, de outro, assume em relação a ele leve distância. A dialética de Eisenstein ganha, com a narração sobre as imagens do filme, um tom de rememoração, que oscila entre a proximidade e a distância, entre assumir uma herança e conduzi-la em outra direção. Ao retomar as imagens d'O encouraçado Potemkin como rememoração, parte de uma experiência pessoal e coletiva, Marker parece tingir a dialética por uma dimensão poética e patética (vinculando-a fortemente a um pathos).

A introdução d'O fundo do ar é vermelho traz, assim, um inventário dos corpos em luta, os braços erguidos, os punhos cerrados, as bocas a gritar palavras de ordem. A este, contrapõe-se outro, um inventário dos corpos armados da repressão: ressalta-se a semelhança no modo de marchar, de segurar as armas, de impor barreiras, todo um modus operandi do aparelho repressivo do Estado. A série é atravessada pela dialética e a dialética pela série: uma opõe aos gestos de luta aqueles da repressão; a outra modula essa oposição, compondo afinidades, ressonâncias, que, sem negligenciar os

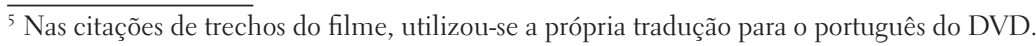


diferentes contextos das imagens, expõem os afetos da revolução e da violência, muito concretamente inscritos nos corpos e nos gestos.
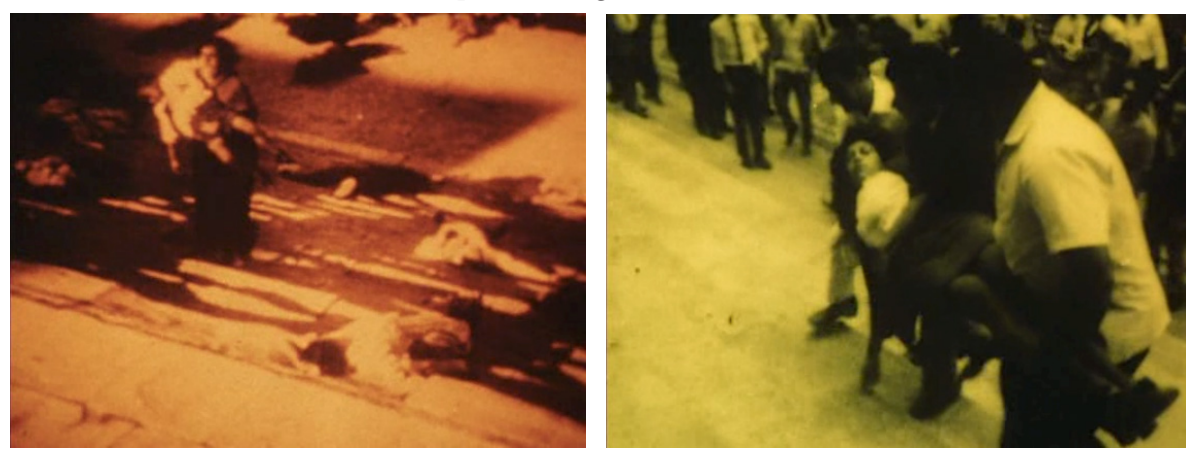

Figura 1: A dialética e a série.

Fonte: Fotogramas retirados d'O fundo do ar é vermelho

\section{La musique nocturne}

La musique nocturne - trilha sonora que "emoldura" o documentário, aparecendo em sua abertura e em seu encerramento - é uma sinfonia composta por Luciano Berio em 1975. Não se trata, porém, de um trabalho original, mas uma transcrição, ou uma montagem na forma de reorquestração, a partir da composição de Luigi Boccherini (1743-1805). Inicialmente composta para um quinteto de cordas, a sinfonia de Boccherini, intitulada La musica notturna delle strade di Madrid, ganhou outras quatro versões, sendo uma delas de 1799, logo após a Revolução Francesa.

Berio descrevia sua música como um novo arranjo para um material musical já existente (algo que repercute o próprio trabalho de retomada dos arquivos por Marker). Em sua apropriação, ele cria uma composição simples, curta, de fácil memorização, que segue e repete o desenho de crescendo e decrescendo, sempre acrescido por alguma sutil alteração. "De fato, à medida que a música vai crescendo, as manifestações vão se transformando em confrontos mais violentos. Mais que as imagens, a música é responsável pela progressão dramática” (CASANOVA, 2013, p. 4 , grifo do autor $)^{6}$.

Encerrada essa trilha enfática, predominam, ao longo de todo o filme, as intervenções sonoras produzidas por sintetizadores que, em diversos momentos, conferem às cenas um tom grave, sombrio ou enigmático. Ao comentar sua escolha por trabalhar com o sintetizador, Marker menciona a infinitude de recursos do

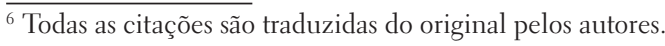


instrumento, recusando o preconceito acerca de sua "inumanidade". Ele revela ter utilizado o sintetizador deliberadamente em seu registro mais agressivo, em oposição ao calor sinfônico da composição de Berio. "Dois modos musicais que se opõem como o calor da ilusão lírica ao gelo da guerra política que é a única realidade (compreendendo-se que todos possuem o direito e, algumas vezes o dever, de negar a realidade)" (MARKER, 1978, p. 24, grifo do autor).

Além de sublinhar certas passagens do filme, a trilha sonora será também uma espécie de comentário - em aliança com o texto verbal e os filtros coloridos conferindo às imagens documentais uma camada dramática (onírica, dissonante). Ela é mais um recurso para que o diretor exerça seu direito (ou seu dever) de "negar a realidade", levando os arquivos a uma região sensível (e de sentido) próxima ao “calor da ilusão lírica”, em recusa ao modo frio e indiferente como a guerra política é construída como realidade única.

\section{Rostos, escuta, pensamento}

Estamos diante de imagens de uma greve, em Saint-Nazaire. Sabemos que foram filmadas, originalmente, para o filme O primeiro de maio em Saint-Nazaire (Le première Mai à Saint-Nazaire, Hubert Knapp e Marcel Trillat, 1967), junto à greve dos trabalhadores da Chantiers de l'Atlantique, uma empresa de construção naval francesa. O filme testemunha o fim de uma greve de dois meses e, após um acordo entre patrões e sindicato, os trabalhadores escutam os discursos de ambos.

O trecho se inicia silencioso. Um senhor mira a câmera e logo desvia seu olhar para o fora de campo, para onde olham os demais. O travelling move-se da direita para a esquerda, em um movimento suficientemente lento para destacar os rostos apreensivos, compenetrados, atentos a algo que permanece ainda no fora de campo da imagem. O ponto de vista daquele que filma é interior ao acontecimento; avizinha-se aos sujeitos que dele participam.

A proximidade da câmera em relação às pessoas filmadas - um a um, ela filma aqueles que não lhe devolvem o olhar - permite apreender a forma sensível da escuta dos operários, uma escuta ativa daqueles que elaboram o que ouvem. Ao filmar tão detidamente suas expressões, o cinegrafista os toma como sujeitos do acontecimento que também os atravessa (e que atravessa também a câmera).

A retomada das greves operárias no início d'O fundo do ar é vermelho instaura um argumento - uma inquietação - que, ainda que não totalmente explícito, conduzirá a montagem de Marker. Trata-se, como bem observa Carolina Aguiar (2013), de um balanço autocrítico, que se marca pela apreensão com o caráter fragmentado da luta 
de esquerda, apontando ao mesmo tempo para a possibilidade de unidade que não se realize sob o modo da violência, algo que se vislumbra com a emergência, na Europa, de uma "nova esquerda" (à qual o diretor dedicará afinal o seu filme).

Se a dimensão sensível é, contudo, ressaltada, o será no sentido de que o retrospecto (o "balanço") elaborado pelo filme não se faça totalmente distanciado da contingência dos acontecimentos, abstraído dos momentos concretos - testemunhados pela câmera - em que a história se faz, a hesitação inscrita nos rostos dos sujeitos que dela participam.

Há, assim, um pensamento sensível, nascido do testemunho da câmera, que interessa a Marker preservar - ele emerge do encontro entre um modo de filmar (a duração, a atenção à singularidade dos rostos, seu pertencimento a um coletivo) e um modo de experiência: os trabalhadores, homens e mulheres que escutam e elaboram sua própria história, no momento mesmo em que ela se constitui. Antes mesmo da montagem, a câmera pensa: pensa que, em sua escuta, aqueles que ela filma pensam, se posicionam diante da história que eles mesmos estão construindo. A retomada que Chris Marker fará d'O primeiro de maio em Saint-Nazaire (e de outros filmes militantes) nos devolve essa espécie de matéria sensível cujo acesso só se fez possível porque aqueles que registraram as imagens - militantes-cineastas, cineastas-militantes - compartilharam o momento contingente da história. Marker valoriza e se detém nesse momento de atenção e de escuta, conferindo espessura à grave hesitação dos trabalhadores.

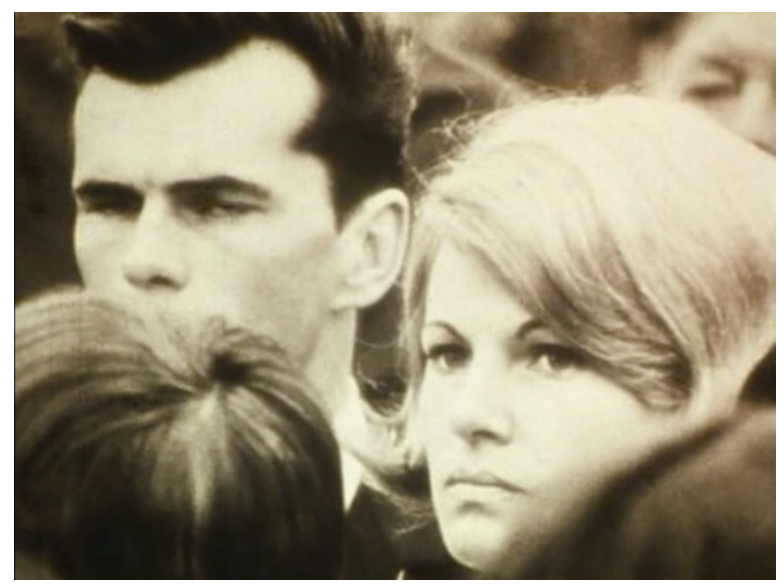

Figura 2: A câmera e a escuta.

Fonte: Fotograma retirado d'O fundo do ar é vermelho 
E então, as imagens se agitam, se inquietam, ganham ritmo diferente dessa escuta grave. Um tremor subterrâneo parece ligar os discursos, as ações e os gestos de militantes em várias partes do mundo. A entrada dos estudantes na cena política insinua-se frágil diante do aparelho de Estado organizado em suas formas repressivas. "Nunca esqueceremos como começou esse carrossel da morte", nos diz Cohn-Bendit, referindo-se ao atentado contra Rudi Dutschke. Ou em outra frase célebre, enunciada nesse contexto, por Maspero (ao comentar o livro de Régis Debray (1980): "Não imaginem que apenas um livro comece a revolução”.

\section{De uma mão a outra}

Em pouco mais de um minuto, Marker retoma planos de origens e naturezas bem distintas, sintetizando o que entende por “mãos frágeis”, expressão que nomeia a primeira parte d'O fundo do ar é vermelho.

Os cinco primeiros planos são de rostos, rostos dos jovens misturados ao rosto de um mito, Che Guevara (cuja estampa se vê por toda parte). Sobre a imagem da face de uma bela garota de cabelos ruivos em uma manifestação, retorna a voz de Simone Signoret: "O ano de 1967 viu surgir uma raça de estranhos adolescentes. Eram todos parecidos. Eles se reconheciam. Pareciam habitados por um conhecimento absoluto sobre algumas questões e sobre outras, não sabiam nada”.

Segue-se, em um corte deliberadamente violento, a imagem de um garoto africano, ferimento aberto em sua face. Outras virão e dizem daquelas realidades que os estudantes, em alguma medida, desconheciam: África, Índia, Vietnã, América Latina... Por meio da montagem, Marker parece expor uma distância entre as mãos frágeis dos estudantes e as mãos sofridas dos trabalhadores, entre o rosto maquiado da jovem e o rosto ferido da criança negra. Explicitada essa distância, a montagem da série apresenta uma agitada circulação: mãos que colam cartazes, mãos algemadas, mãos trabalhando, mãos que operam armas, mãos que repousam sobre o peito e mãos que tateiam livros em uma estante. Ao que responde a narração, por meio da voz over: “Os operários pegarão das mãos frágeis dos estudantes a bandeira da luta".

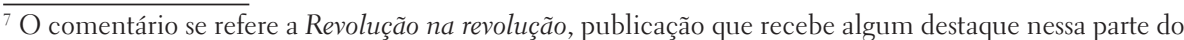
filme como emblema da utopia revolucionária e referência para os movimentos de guerrilha. Por outro lado, foi posteriormente alvo de severas críticas. O livro, sabemos, representava uma ruptura com os partidos comunistas históricos, defendendo a formação de uma vanguarda política revolucionária que partiria para a luta armada.
} 

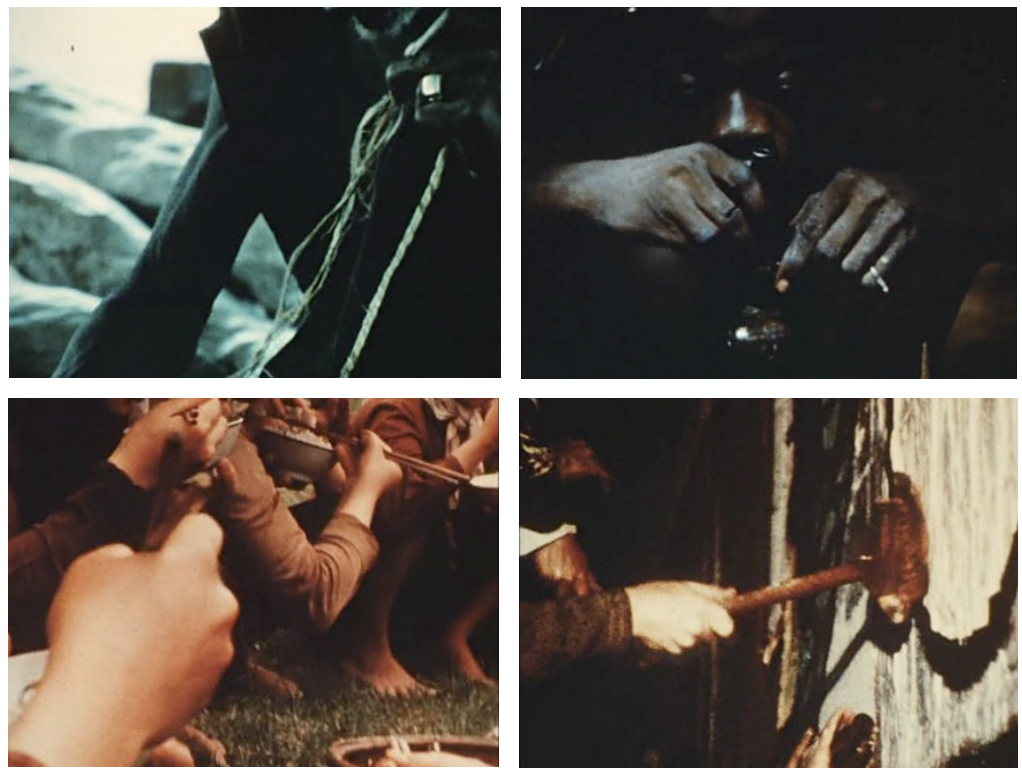

Figura 3: As mãos.

Fonte: Fotogramas retirados d'O fundo do ar é vermelho

A montagem paratática associa imagens heterogêneas que, a partir da relação "lateral" com o comentário, produzem uma espécie de comunidade: comunidade política, comunidade fílmica (construída pela montagem), que se constitui por uma aproximação - um apelo -, não sem deixar de marcar sensivelmente uma distância.

\section{"Por que as imagens se põem a tremer?"}

Sobre o som de sintetizador, vemos imagens alaranjadas e extremamente instáveis de policiais parados, espingardas às mãos: "Pourquoi" (por que); "quelquefois" (às vezes); “les images” (as imagens); “se mettent-elles” (se põem); “à trembler?” (a tremer?).
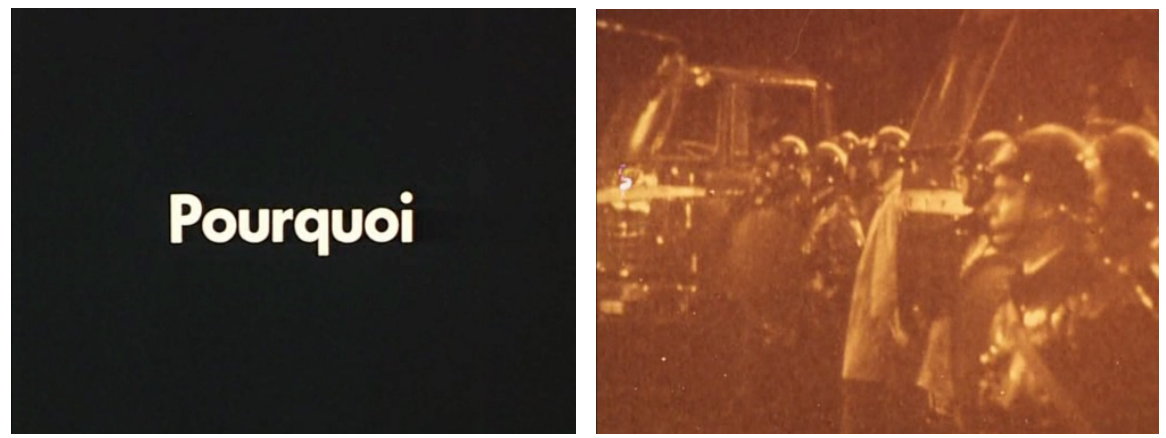


\section{quelquefois}

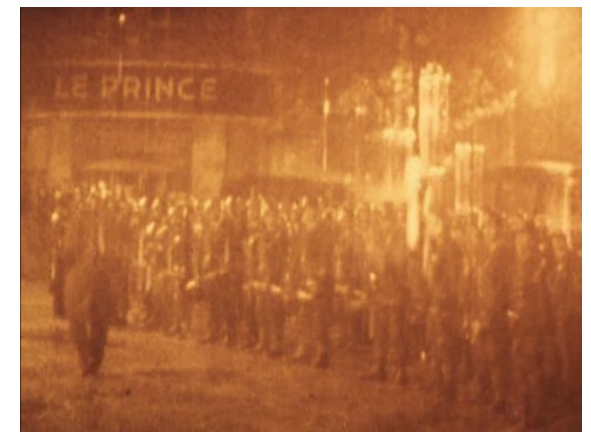

\section{lesimages}

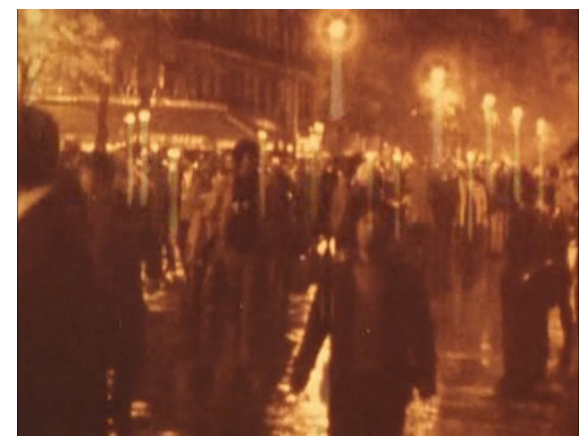

\section{se mettent-elles}

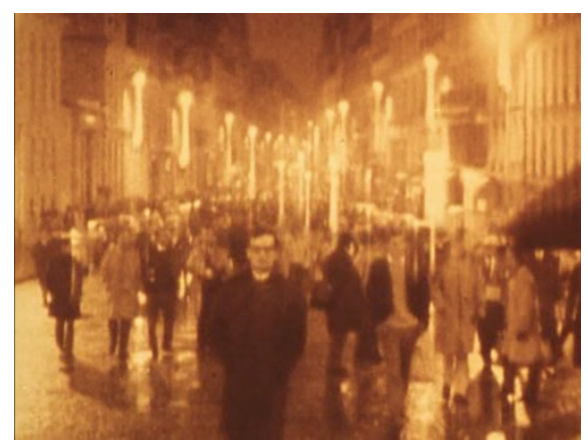

\section{d trembler?}

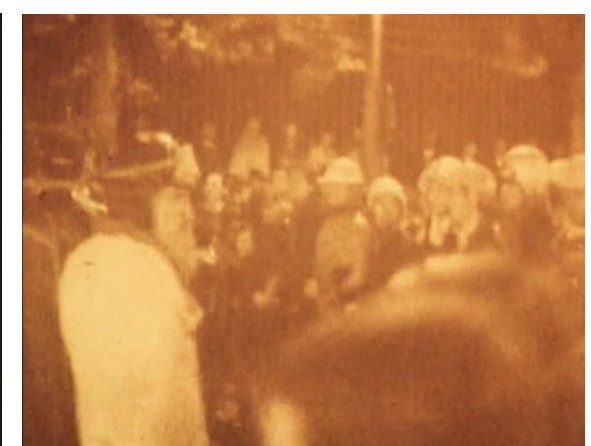

Figura 4: Por que as imagens se põem a tremer? Fonte: Fotogramas retirados d'O fundo do ar é vermelho 
Ouvimos então a voz de Marker: "Aconteceu comigo em maio de 68". Uma nova sequência inicia-se, também acompanhada de testemunho, como se conversasse com os anteriores, dessa vez na voz de Davos Hanich: "Comigo foi em Praga... no verão de 1968. Quando vi os takes, estavam tremidos. Eu controlara minhas mãos, mas a câmera captara tudo". E então, outro depoimento, narrado por François Maspero: "Em Santiago do Chile, a câmera entrou em câmera lenta sozinha. Talvez pela emoção de ver ao contrário essas mangueiras que eu vira tantas vezes usadas nas manifestações de esquerda em Berlim, em Louvain, nos Estados Unidos”. Em imagens azuladas das ruas de Santiago, um carro de polícia dispersa manifestantes com jatos de água. A câmera lenta altera a percepção do evento: como se houvesse algo de estranho e específico nessas imagens da repressão, diferenciadas formalmente em relação às anteriores.

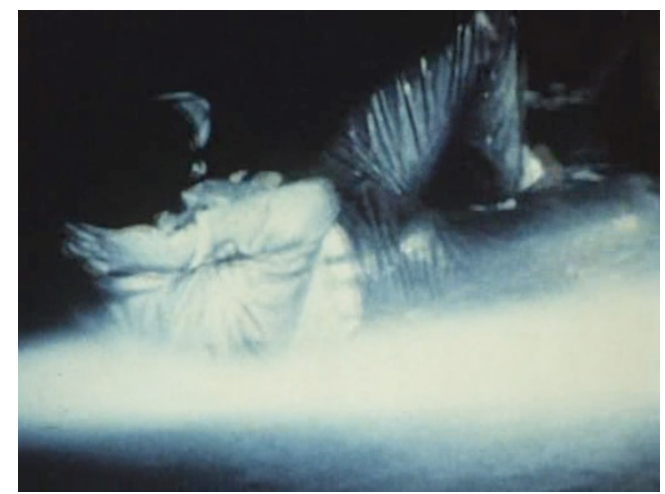

Figura 5: A câmera lenta.

Fonte: Fotograma retirado d'O fundo do ar é vermelho

Entremeada às imagens e seguidas dos testemunhos fragmentados dos cinegrafistas, a questão - Por que as imagens se põem a tremer? - marca um momento crítico do filme. Ela é contígua às mãos frágeis, que tremem diante da hesitação da própria esquerda: a inesperada falha técnica aparece como indício do inesperado da história (pequeno lapso que demonstra como a história não segue em linha reta): se a violência reaparece, virá agora de governos de esquerda: no Chile, em Praga...

O tremor das imagens diz respeito a sua força testemunhal diante de uma urgência, em que a repressão se inscreve no corpo do cinegrafista, alterando sua composição. Como dirá Anita Leandro (2010, p. 102), evidenciar o tremor das imagens é o modo de "tornar sensível o apelo distante da imagem de arquivo", testemunha ainda viva do passado. O tremor remete ainda, segundo a autora, à gravidade do momento filmado, não se restringindo a um problema estritamente estético. A retomada das imagens por Marker refere-se a um "projeto comum de resistência por meio do 
cinema" (LEANDRO, 2010, p. 102), expondo a multiplicidade dos pontos de vista nos momentos mais intensos de urgência e, ao mesmo tempo, de vulnerabilidade.

A pergunta de Marker acusa a tensão - o tremor - nascida do acirramento das cisões de esquerda, que viu emergir, em seu interior mesmo, as cenas de violência. Na montagem, à distância dos acontecimentos, a indagação torna-se possível por conta das imagens, agora articuladas aos depoimentos dos cinegrafistas. O cinema militante expunha, naquele momento, a impossibilidade de se filmar fora do mundo.

\section{"Uma revolução passou por aqui"}

Dez de maio de 1968, noite das barricadas. Sobre cenas de confronto entre os estudantes e a ostensiva repressão policial, ouvimos a análise de Jorge Semprún: "Há um erro duplo nessas situações. O Estado revela de repente sua face repressora". Nesse momento, o áudio original do registro, o estrondo de uma bomba, interrompe a frase (como se a violência nas ruas atravessasse o comentário, interditando-o). O Estado se revela ao manifestante "como a Santa Virgem para Bernadette".

Uma série de imagens do confronto, em colorações diferentes, mostra a ressonância do acontecimento em outros países: a repetição dos gestos na série permite apreender a vizinhança entre um e outro contexto. Permite apreender também variações e diferenças.

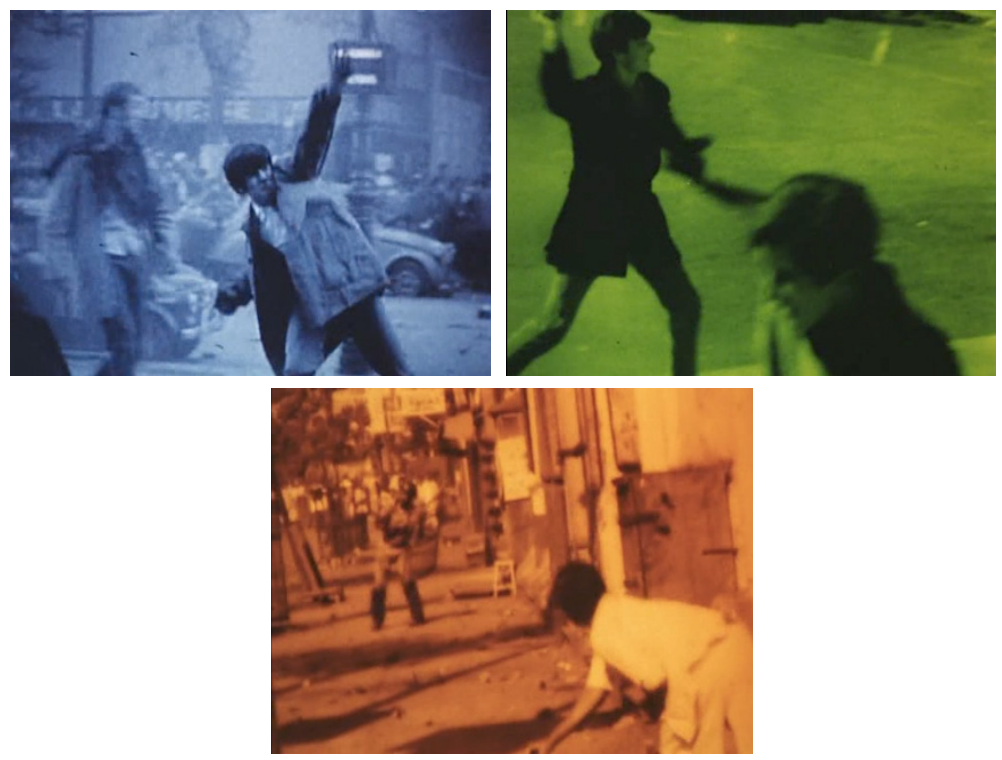

Figura 6: As barricadas.

Fonte: Fotogramas retirados d'O fundo do ar é vermelho 
Novamente, um plano desacelera a série: na imagem em câmera lenta (acirrada pela trilha sonora também desacelerada), um policial atinge o rosto de uma mulher, atirando-a contra a parede, sublinhando a violência crescente.

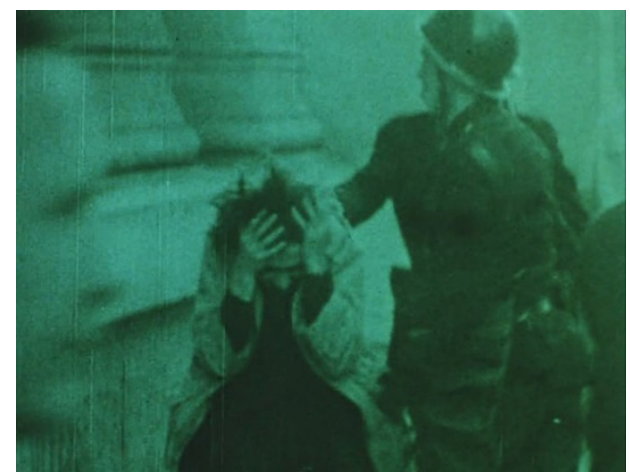

Figura 7: Escalada da violência.

Fonte: Fotograma retirado d'O fundo do ar é vermelho

Longe da escalada da violência nas ruas, agora em um estúdio de televisão, Alain Peyrefitte, ministro da Educação da França em 1968, é entrevistado. Ele dirá “sim” ao diálogo e "não" à violência. A aparição silenciosa do rosto de Daniel Cohn-Bendit (aliada à abrupta e desmedida repressão exposta nas cenas anteriores) opõe-se, breve e incisivamente, à fala do ministro. Em planos avermelhados, vemos precariamente uma manifestação do 10 de maio à Rua Gay Lussac, em Paris, enquanto ouvimos a narração de rádio: "A juventude está expressando seu ódio por uma certa sociedade e construindo barricadas". Como antecipara Jorge Semprún, o Estado nos impede de atravessar a rua. "Mas se eu a atravessar, se faço a coisa recuar, é o Estado que recua".

Na relação entre revolta e repressão, entre revolução e contrarrevolução, a espiral do tempo aparece sensivelmente na imagem como escalada da violência, algo que, nos termos de Aguiar (2013), configura uma espécie de dialética espiralada.

Cabe notar o quanto o áudio se torna protagonista na retomada do Maio de 1968: enquanto, nas imagens, vemos a preparação das barricadas - os manifestantes arrancam paralelepípedos do chão, passam as pedras de mãos em mãos (novamente, a pulsão revolucionária que se transmite pelas mãos) -; no áudio, gravações de rádio repercutem os acontecimentos em tom alarmista. Por meio do áudio, convocando todo tipo de discurso (do testemunho às vozes over, das cartas às notícias no rádio), Marker traz para o interior do filme a agonística de Maio de 1968, esse que foi, segundo Pierre Nora, um festival da palavra ativa (NORA, 1972, p. 163). Vale notar 
como, agora em um gesto de distanciamento (sempre relativo), o espaço over do filme preserva essa dimensão ativa e coletiva da palavra: não à toa, as vozes over, constituintes de uma polifonia, são enunciadas por atores, atrizes, amigos, intelectuais e militantes ${ }^{8}$, todos, de uma forma ou de outra, participantes do acontecimento, o que torna o comentário perspectivado: distanciado, mas implicado.

Vemos, então, uma imagem estática da silhueta do prédio da Sorbonne, ao crepúsculo. Momento das indistinções, o crepúsculo indica o dia posterior ao acontecimento, quando as palavras silenciam, ainda que provisoriamente.

A série será retomada - a eclosão da violência e a prisão de manifestantes em várias partes do mundo - cada sequência destacada por uma tonalidade distinta. $\mathrm{O}$ comentário lança luz agora sobre o contexto latino-americano (já tematizado no filme por meio da guerrilha9 ) e antecipa o protagonismo que Salvador Allende ganhará adiante. Os resultados políticos não são proporcionais à violência, nos diz a narração.

\section{Nunca se sabe ao certo o que se filma}

A primeira parte d'O fundo do ar é vermelho termina com uma referência ao Festival de Avignon ${ }^{10}$ e a proibição da exibição do espetáculo Paradise Now na edição de 1968. Os estudantes se manifestam e culpam Jean Villar - o diretor do festival pelo ocorrido. "Mas a história não seria feita em Avignon em 68... e sim em Praga", ironiza a voz over: o mais importante - a repressão soviética ao processo de abertura em Praga - estaria acontecendo em outro lugar.

Estamos na segunda parte do filme: As mãos cortadas. Emil Zatopek é anunciado por uma narração feminina. Nas Olimpíadas de Helsinque, na Finlândia, em 1952, Zatopek quebrou recordes de atletismo, tornando-se conhecido como "locomotiva humana". Quando em 1968 decidiu apoiar a Primavera de Praga, foi expulso do partido comunista - ligado à URSS - e, com isso, deixou de representar o país como atleta.

\footnotetext{
${ }_{8}^{8}$ No caso, a atriz Simone Signoret, amiga de longa data de Marker; Jorge Semprún, importante escritor e político espanhol; o editor François Maspero, que publicou, entre outras leituras importantes para a esquerda francesa, o livro de Debray; a atriz Sandra Scarnati; e os atores Yves Montand, François Périer e Davos Hanich, que atuou em La Jetée.

${ }^{9} \mathrm{O}$ filme de Marker é atravessado pela questão da guerrilha, apresentada em sua ambivalência. Ela aparece como força histórica decisiva, criadora e surpreendente. Demonstram-se, ainda e contudo, seu fracasso e sua derrocada como alternativa para a luta de esquerda em direção ao socialismo.

${ }^{10}$ Festival de teatro anual fundado por Jean Villar.
} 
Marker comenta as imagens que fez de Zatopek, em 1952, nos Jogos Olímpicos de Helsinque, parte de seu longa-metragem de estreia, Olympia 52 (1952). O que naquele momento parecia um hiato de paz na Guerra Fria, diz o comentário, seria contrariado pela Guerra da Coréia.

Após imagens da Guerra da Coréia - cujo caráter intolerável é acentuado pela trilha sintetizada -, Marker retoma seu comentário: o cozinheiro da equipe da Coréia do Sul em Helsinque, ele conta, ganhara a maratona de 1936, filmado pelas câmeras de Leni Riefenstahl. Mas, na época, ele era japonês: "Nunca se sabe o que se filma. Leni Riefenstahl pensara ter filmado um japonês, mas filmara um coreano". Mais à frente, sobre imagens de uma competição de hipismo, Marker continua: "Eu, seguindo o campeão de salto chileno pensava ter filmado um cavaleiro, mas filmara um putschista que se tornaria o general Mendoza da junta de Pinochet. Nunca se sabe o que se filma".

Ressaltando a intrincada conexão entre as Olimpíadas e a geopolítica da Guerra Fria, Marker enfatiza a opacidade da relação entre a história e as imagens, que, como seu documento, são, de um lado, marcadas por uma parcela de não saber, de inconsciência. Por outro lado, contingente, o momento da tomada demanda sua retomada na montagem, o que confere sempre novos sentidos para as imagens, reconfiguradas em sua historicidade. Em $O$ fundo do ar é vermelho, a montagem parece preservar essa dupla dimensão das imagens: antes, esse não saber que constitui uma legibilidade atenta à matéria sensível das imagens. E então a reconfiguração de seu sentido, dada pelo distanciamento histórico e pela própria historicidade dos documentos. Essa distância, contudo, não se configura como instância de "julgamento" da história, seu fechamento ou solução, mas como reposicionamento crítico que prolonga a consciência da opacidade de todo ponto de vista.

\section{A luta e o luto}

Um corte nos leva bruscamente a uma sequência totalmente silenciosa. Trata-se de um registro do funeral de Jan Palach, estudante tcheco que, aos 20 anos de idade, ateou fogo ao próprio corpo na praça de São Venceslau, em Praga, no dia 16 de janeiro, como forma de protesto contra a invasão da União Soviética. O funeral é tornado protesto: ato silencioso, em que as pessoas mal se movem, guardam expressões graves, tristes, consternadas. Em movimentos ágeis, a câmera transita pelos rostos. Um bonde passa interrompendo o silêncio, mas não dispersa a pequena multidão. A agitação da história parece momentaneamente suspensa. A câmera transita pelos rostos imobilizados. O salto se produz entre as imagens 
agitadas e ruidosas da manifestação (na sequência anterior) e essas congeladas, do luto tornado protesto.

A morte de Jan Palach se liga a outros funerais do filme. Da morte de Che Guevara àquela de Salvador Allende, passando pelo assassinato e desaparecimento de inúmeros militantes em várias partes do mundo, o luto atravessa - como espécie de sombra crepuscular - a história da revolução tal como retomada por Marker.

Na cena seguinte, de modo disruptivo, nos deparamos com uma transmissão da ORTF (órgão público de radiodifusão e televisão francês), da comemoração de 2.500 anos da monarquia do Irã em Persépolis. O xá do Irã recebe os convidados, chefes de Estado de diversos países, entre eles Leonid Brezhnev, então presidente da URSS, país que dominava a Tchecoslováquia e contra o qual Jan Palach protestava quando de sua morte. Um corte e nos deparamos com um cartaz de recompensa pela captura de Ulrike Meinhof, uma das fundadoras do grupo de Baader-Meinhof. O grupo surgiu como uma reação à morte do estudante alemão Benno Ohnesorg em 2 de junho de 1967, em uma manifestação em Berlim, justamente contra a visita do xá do Irã à cidade. Na época, Ulrike Meinhof, que era jornalista, escreveu um artigo criticando a visita do xá, que apoiava os Estados Unidos na Guerra do Vietnã (PREECE, 2012). A câmera aproxima-se do rosto de Ulrike, estampado no cartaz. Em uma breve aparição, Larry Bensky, jornalista e ativista político, diz em entrevista: "Se você quer se tornar um revolucionário, deve se lembrar, embora não seja um pensamento alegre, que um dia qualquer você pode simplesmente..."

... morrer (é o que sugere o gesto de Bensky). Essa entrevista serve como introdução para os planos seguintes que compõem uma série - das mais belas do filme - por meio da qual se rememoram e homenageiam os militantes presos ou assassinados. São as mulheres que abrem a série, o que reforça a atenção de Marker à presença feminina nas lutas. Como indicado pela inscrição na tela, a imagem seguinte mostra o evento em que Margrit Schiller, que se juntou ao grupo de Baader em 1970, foi presa em Hamburgo, em 22 de outubro de 1971. Ela abaixa a cabeça para que seu rosto não seja fotografado ou filmado, mas um dos policiais força violentamente sua exposição. A violação se repete com Ulrike Meinhof que, com os olhos fechados, os dentes cerrados e as sobrancelhas raspadas, parece tentar resistir ao policial que segura seu rosto ${ }^{11}$.

\footnotetext{
${ }^{11}$ A violação, que passa pela obrigação de exposição do rosto, nos lembra das mulheres argelinas fotografadas por Marc Garanger: ele era soldado do exército quando, durante a guerra da Argélia, obrigava as mulheres a retirar o véu de modo a fotografá-las para a carteira de identidade. Anos depois, Garanger recupera as fotos e as expõe, mostrando o quanto uma imagem pode ser violenta. Mostra também como, submetidas a essa violação, as mulheres resistem, resistência inscrita na expressão de seus rostos.
} 
Vemos então um cartaz com o desenho do rosto de Tamara Bunke, conhecida como Tania, guerrilheira comunista que lutou junto de Che Guevara e faleceu em 31 de agosto de 1967 em uma emboscada na Bolívia. Uma marcha de mulheres em Cuba homenageia Tania. Lentamente, outros nomes são enunciados, cada um por um narrador diferente e, o mais importante, sempre na pronúncia da língua nativa do militante: Ulrike, Tania, Sarita (em referência à cineasta militante cubana Sara Gomez), Nguyen Van Troi, Javier Heraud, Malcolm X, Camilo Torres, Txiki, Ben Barka, Miguel Enríquez, Victor Jara, Julián Grimau, George Jackson, Carlos Marighella, Roque Dalton... As mortes guardam em comum o período em que ocorreram e a precocidade das vítimas, que tinham todos entre dezenove e quarenta anos de idade.

A série enumera, nomeia, monta sem hierarquizar ou explicar as histórias ali inventariadas. Dispõe, lado a lado, as vidas exemplares dedicadas à luta; marca sua singularidade e, ao mesmo tempo, os reúne em um lugar comum: comunidade política cujos sujeitos dispersos são avizinhados pelo filme. Ao colocar lado a lado os jovens mortos na luta revolucionária, sujeitos muitas vezes anônimos, Marker explicita, em uma montagem por contato, dois motivos essenciais ao filme: o luto e a luta. De um lado, cabe nomeá-los, conferir a eles um lugar na história. De outro, elaborar seu luto ou, ao menos, reivindicá-lo por meio da montagem: trata-se, por um lado, de afirmar uma comunidade política, de outro, acusar e recusar a violência que ameaça essa afirmação.

\section{Os gatos e o poder}

Os gatos, animais pelos quais Marker possui assumida admiração, protagonizam toda uma sequência d'O fundo do ar é vermelho. Mais uma vez, a série paradigmática será o modo de montagem acionado por Marker: a sequência percorre um caminho que vai do funeral de Georges Pompidou às manifestações em Minamata, no Japão.

Sintetizador ao fundo, Marker ironiza a figura Richard Nixon, então presidente dos Estados Unidos, no funeral de Pompidou: "Nixon está de cara feia na catedral de Notre Dame. Está preocupado. Aliás, todos os chefes de Estado estão pálidos”. Ao narrar, ele próprio, o trecho sobre os gatos, o diretor reforça sua afinidade. "O poder não traz saúde. Basta olhar para eles para ver. Ou comparar com o olho de um gato. Essa é a prova da verdade, o critério absoluto. Um gato nunca fica do lado do poder".

Após as imagens do funeral, inicia-se uma sequência da Cat Parade, na cidade de Ypres. A sequência dos gatos nos pareceria inusitada não fosse a conhecida fixação de Marker por esses animais e a desconfiança que, por meio do olhar felino, o diretor endereça ao poder. Jacques Rancière nos lembra que esse fetiche é compartilhado por 
outros diretores de cinema, especialmente os "dialéticos": de Sergei Eisenstein a Chris Marker, o gato é "aquele que converte uma besteira em outra, que remete as razões triunfantes às superstições burras ou ao enigma de um sorriso” (RANCIÈRE, 2012, p. 60).

Os gatos estão agora em convulsão. Saberemos à frente, que eles sofrem os efeitos da intoxicação devido ao despejo de mercúrio na água pela Companhia Chisso, em Minamata. A série prossegue com um jovem também sob efeito do mercúrio. Pausadamente, Sandra Scarnati, por meio da voz over, diagnostica uma mudança no modo de operar dos poderes, que antes oprimiam ou matavam diretamente e que, agora, portam a morte como subproduto de sua atividade. "No Japão, a Companhia Chisso envenena as águas de Minamata com mercúrio. Os pescadores e suas famílias sofrem com o que eles chamam de 'doença'. Crianças doentes vêm ao mundo."
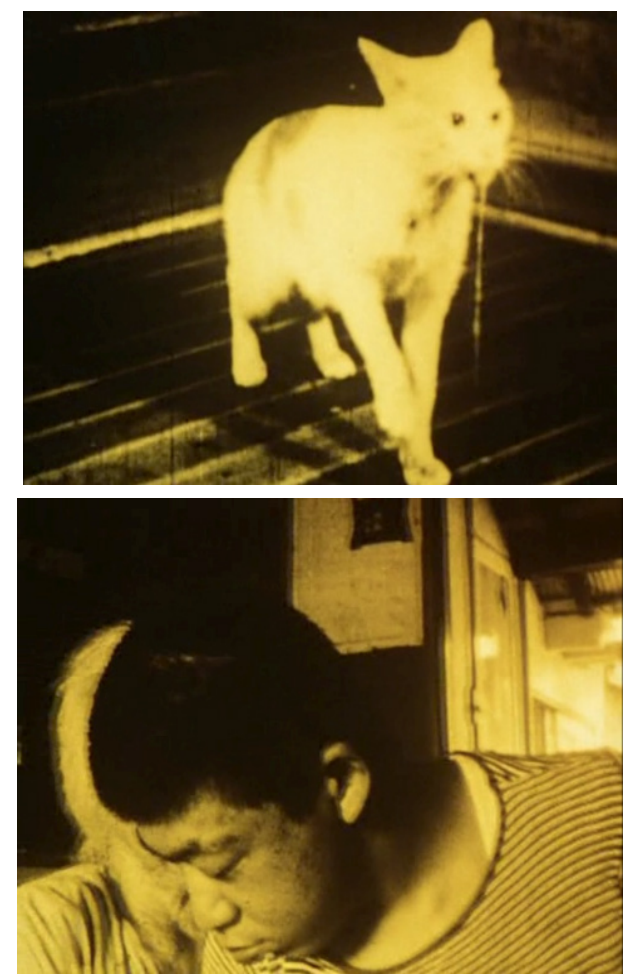

Figura 8: Convulsão.

Fonte: Fotogramas retirados d'O fundo do ar é vermelho

O poder torna-se insidioso, esquiva-se na mesma medida em que deixa consequências danosas para as vidas. Por meio do comportamento dos gatos, o que 
seu olhar sutilmente expressa ou o que seu corpo sofre, a série acompanha essa transformação do poder, de um a outro contexto.

\section{"Poeta do poema cinematográfico"}

No início deste artigo, notávamos a intenção expressa por Marker em acessar o "tempo da reflexão". De um lado, essa reflexão é acompanhada pelo interesse naquilo que advém da história e que deixa seus traços em imagens cinematográficas, constituindo uma ponta visível e uma parte submersa, que exige o trabalho arqueológico de escavação. Por outro lado, se a reflexão precisa, como sempre, distanciar-se para comentar as imagens, esse distanciamento não será demasiado, mas sempre relativo e o comentário se fará próximo à matéria sensível da história. A reflexão reivindicada por Chris Marker mostra-se fazendo menos sobre as imagens do que com as imagens, para construir uma legibilidade que emerge do contato entre elas, em seus intervalos, em suas oposições e sua comunidade. O fundo do ar é vermelho exercita assim um ensaísmo coletivo, que não apenas retorna à "palavra ativa” em torno de Maio de 1968, mas se expande e convoca sua matéria sensível, testemunhal, sempre marcada por certa opacidade.

O filme mostra, afinal, como a história do cinema é indissociável da história moderna, que tem, em seus arquivos submersos, uma virtualidade capaz de conferir a ela renovadas legibilidades. Não é nesse sentido que Marker pode ser visto como "poeta do poema cinematográfico"? (RANCIÈRE, 2013) Atento à parte submersa das imagens e às suas variações sensíveis, seu trabalho nos devolve aqueles momentos em que a história hesita, em que - aquém ou além dos discursos - a palavra silencia, as imagens religam sua ponta visível à sua virtualidade não visível.

\section{Ainda há lobos, cine-matilha}

O filme, sabemos, possui quatro versões: é importante, portanto, ressaltar, que ele será atravessado pelas transformações históricas que ocorrem ao longo de 21 anos. Na obra de Marker, há um período de engajamento intenso no cinema militante, particularmente aquele dos coletivos cinematográficos, desde 1967, com Até logo, eu espero. Em O fundo do ar é vermelho, vemos uma reelaboração desse período através da montagem das imagens produzidas num momento de efervescência política. A cada nova versão, a montagem das imagens advindas de fontes heterogêneas abre um processo de mise en abyme de sucessivas retomadas. Uma vez que tomamos a compreensão da história como algo inacabado e 
contingente e não como um progresso ininterrupto e inevitável, a historicidade seria construída pelo cinema já no momento da tomada e, posteriormente, na montagem, em várias retomadas.

Nas diferentes montagens, nenhuma nova imagem é acrescentada, mas o comentário ganha um tom reflexivo. Marker remonta à versão de 1977, para, em sua versão de 1998, ao final do filme, comentar que a história "tem mais imaginação que nós". Vemos então imagens não identificadas de lobos que correm em um campo aberto enquanto são alvejados por tiros vindos de um helicóptero (a mesma imagem aparecera, de relance, em uma sequência da captura e assassinato de Che Guevara). A narração retorna, com um consolo: "15 anos depois ainda havia lobos”.
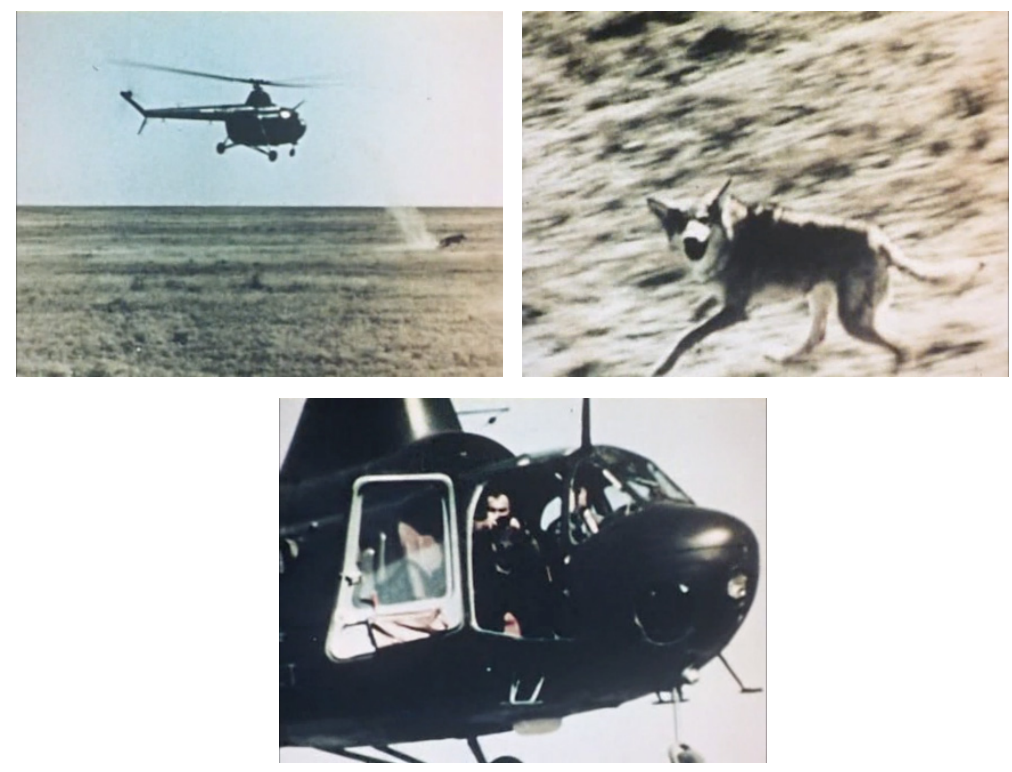

Figura 9: Filme impossível.

Fonte: Fotogramas retirados d'O fundo do ar é vermelho

No sétimo episódio de História(s) do cinema (Jean-Luc Godard, 1988-1998), "Le contrôle de l'univers", após os créditos finais, reencontramos as imagens dos lobos do filme de Marker entrecortadas pela inscrição "filme impossível". Talvez, a sugerida impossibilidade do filme se ligue à fragilidade do cinema - que é, ao mesmo tempo, sua força: ele não pode salvar ou ressuscitar os mortos. Mas, como argumenta Scemama (2015, p. 246), pode trazê-los de volta à imagem e assim "salvar a honra de todo o real". 
Digno de nota que a "salvação" se faça com e pelas mãos, que predominam ao longo desse último episódio da série godardiana (assim como em toda a série). "O cinema é a mão [...], ou seja, o que faz, o que está em ato" (BÉGHIN, 2007, p. 32). "A verdadeira condição do homem é de pensar com suas mãos", diz Godard, anunciando uma proletarização do pensamento. Vale ressaltar ainda que a “salvação" se produza de uma mão à outra, em um trabalho coletivo, muitas vezes, anônimo. Como explicita Marker nos créditos finais, O fundo do ar é vermelho só se tornou possível por conta dos registros produzidos por "câmeras, operadores de áudio e militantes cujo trabalho se opõe constantemente ao dos poderes que nos prefeririam sem memória”. Se o filme parece lançar sobre a história um tom crepuscular - a luta revolucionária que se acompanha da morte e da violência -, a elaboração do luto será possível por conta das imagens que entrelaçam inextricavelmente o cinema à história: imagens produzidas, tantas vezes, de modo coletivo por militantes nos mais diversos e adversos contextos e situações. Imagens subterrâneas, tremores, que o filme assume como tarefa escutar.

\section{Referências}

AGUIAR, C. A. O Chile na obra de Chris Marker: um olhar para a Unidade Popular desde a França. 2013. Tese (Doutorado em História) - Universidade de São Paulo, São Paulo, 2013.

ALTER, N. Chris Marker. Chicago: University of Illinois Press, 2006.

BAECQUE, A. "Le fond de l'air est rouge" de Chris Marker, les années rebelles. Rue 89, Paris, 15 abr. 2008. Disponível em: <https://goo.gl/xienHC>. Acesso em: 15 maio 2017.

BÉGHIN, C. História(s) do cinema: invenção da animação. Devires, Belo Horizonte, v. 4, n. 1, 2007.

CASANOVA, V. Écouter l'histoire ou la clé des luttes passées: sur le générique du Fond de l'air est rouge, de Chris Marker (1977). Écrire l'histoire, Marseille, dez. 2013. Disponível em: <https://goo.gl/coEL5o>. Acesso em: 7 maio 2017.

FAIRFAIX, D. Le montage comme résonance: Chris Marker et l'image dialectique. Senses of cinema, Melbourne, set. 2012. Disponível em: <https://goo.gl/4nDtk7>. Acesso em: 7 maio 2017.

GIRAUD, F. Le fond de l'air est rouge de Chris Marker (1977). DVD Classik, Paris, 30 out. 2013. Disponível em: <https://goo.gl/oxgpyT>. Acesso em: 7 maio 2017. 
LEANDRO, A. O tremor das imagens: notas sobre o cinema militante. Devires, Belo Horizonte, v. 7, n. 2, p. 98-117, 2010.

LEONEL, N. B. A. Chris Marker e as barricadas da história: comentários em torno de Le fond de l'air est rouge. 2010. Dissertação (Mestrado em Comunicação e Artes) Universidade de São Paulo, São Paulo, 2010.

LUPTON, Catherine. Chris Marker: memories of the future. Londres: Reaktion Books, 2005.

MARKER, C. Le fond de l'air est rouge: textes et description d'un film de Chris Marker. Paris: François Maspero, 1978.

NORA, P. L'événement monstre. Communications, Paris, v. 18, p. 162-172, 1972.

PREECE, J. Baader-Meinhof and the novel: narrative of the nation / fantasies of the revolution, 1970-2010. Nova Iorque: Palgrave Macmillan, 2012.

RANCIÈRE, J. O destino das imagens. Rio de Janeiro: Contraponto, 2012.

. A ficção documentária: Marker e a ficção da memória. In: . A fábula cinematográfica. Campinas: Papirus, 2013.

SCEMAMA, C. 1988-1998: histoire(s) du cinéma. In: ARAÚJO, M.; PUPPO, E. (Orgs.). Godard inteiro ou mesmo em pedaços. São Paulo: Heco Produções, 2015. Catálogo da retrospectiva Jean-Luc Godard.

\section{Referências audiovisuais}

O FUNDO do ar é vermelho. Chris Marker, França, 1998.

HISTÓRIA(S) do cinema. Jean-Luc Godard, 1988-1998.

submetido em: 30 dez. 2017 | aprovado em: 7 abr. 2018 